\title{
The Strategies of Conveying Speaker and Hearer as Cooperators in Conversation Class: Sociopragmatic Analysis
}

\author{
Veronika Listi Ferdini Damopolii (Corresponding author) \\ English Linguistics, Faculty of Humanities, Universitas Padjadjaran, Bandung \\ Jalan Raya Bandung - Sumedang Km 21. Jatinangor, Sumedang 45363, Indonesia \\ Tel: 628-122-034-3434Ｅ-mail: veronika.damopolii@gmail.com
}

\begin{abstract}
Sutiono Mahdi
English Linguistics, Faculty of Humanities, Universitas Padjadjaran, Bandung Jalan Raya Bandung - Sumedang Km 21. Jatinangor, Sumedang 45363, Indonesia

Tel: 62-228-792-0401_E-mail: sutionomahdi@yahoo.com
\end{abstract}

\begin{abstract}
Eva Tuckyta Sari Sujatna
English Linguistics, Faculty of Humanities, Universitas Padjadjaran, Bandung Jalan Raya Bandung - Sumedang Km 21. Jatinangor, Sumedang 45363, Indonesia

Tel: 62-228-792-0401Ｅ-mail: evatuckyta@unpad.ac.id
\end{abstract}

Received: April 16, 2013 Accepted: May 8, 2013 Published: June 24, 2013

doi:10.5296/ijl.v5i3.3901ＵRL: http://dx.doi.org/10.5296/ijl.v5i3.3901

\begin{abstract}
This study explores the strategies of conveying speaker and hearer as cooperators suggested by Brown and Levinson (1987) - the strategy of asserting or presupposing speaker's knowledge of and concern for hearer's wants, the strategy of including both speaker and hearer in the activity, and the strategy of giving (or asking) reasons. The data of the research is taken from conversation class in The Center Bandung, Indonesia. The teachers are the
\end{abstract}




\section{Macrothink}

International Journal of Linguistics

ISSN 1948-5425

2013, Vol. 5, No. 3

Americans and the members are the Indonesians. The writers observe the teachers as the speakers who use the strategies of conveying speaker and hearer as cooperators to make the conversation works. They use those strategies to encourage the students to use English courageously and actively. The goals of this analysis are to know the strategies used by the speakers in the conversation class and to examine the perlocutionary effects caused by the strategy used by the speaker to the hearer. The research uses a qualitative descriptive method. The data are analyzed using a pragmatic approach. The main theory used to analyze the data is the strategies to convey speaker and hearer are cooperators as the strategy in positive politeness, written by Brown and Levinson. The speakers use the strategy of asserting or presupposing speaker's knowledge of and concern for hearer's wants, the strategy of including both speaker and hearer in the activity, and the strategy of giving (or asking) reasons. The perlocutionary effects to the addressees are making them courageously speak English even though some of them are not fluent in English, giving their own opinion, and trying to ask voacbulary in English. The writers also will find out social variables constituted in the conversation.

Keywords: Speaker, Hearer, Conveying cooperator strategies, Positive politeness 


\section{Introduction}

The research is conducted in English conversation class in Bandung, Indonesia to investigate the strategies used by the native speakers to encourage the Indonesians to learn and use English. This research is inspired mainly by the fact that there has been an increasing popularity of native speakers, like from American and England, who interest the Indonesians to learn English with the native speakers. The Indonesians prefer learning English with native speaker to learning English with Indonesia teacher.

The increasing number of English learners in Bandung, Indonesia is likely to be triggered by the necessity to be able to speak English in every aspect area. The effectiveness in learning and speaking English can be achieved through conversation class. It makes the student have no choice to use their ability in English to answer the teachers' questions. In our opinion, the conversation class makes the students use English and the teacher will correct directly if they do mistakes in words, grammar, and pronunciation. This way is very effective than just gives the lesson without asking or involving the students in the class. According to Young (2006: 479), understanding learner's foreign language (L2) learning is very important because through this understanding teacher as well as other related parties can obtain "some useful insights" which they can use to improve the quality of its teaching and learning.

The writers analyze the strategies of conveying speaker and hearer as cooperators suggested by Brown and Levinson (1987) used by native speakers in the Center Bandung, Indonesia to make the conversation between the native speakers and the Indonesians work. The Center Bandung, Indonesia is different from other English conversation classes in Indonesia. The Center Bandung is established by the Americans and offers the Indonesians to come and join in the activity together. They invite the Indonesians to come and do conversation with them anytime; there is no regular time to come. The native speakers create familiar surrounding and close relationship among the members. They expect the Indonesians to learn and practice their English a lot. The native speakers sometimes asks the Indonesian to hang out or do sport outside. Those make The Center Bandung become different. Other English courses in Indonesia always offer courses in the class with regular time. It interests the writers' attention to analyze the native speakers as the teachers, even though they are not introduced themselves as teachers. Their job is to help the Indonesians to speak English. The writers see the native speakers use the strategies of conveying speaker and hearer as cooperators in the conversation class.

The members of The Center Bandung, Indonesia are the college students in some public universities in Bandung and the workers in Bandung. The writers consider that the members in The Center Bandung are the people who have motivation in practicing, learning, and improving English. In the data analysis, the writers choose students college students as the members in conversation class. The native speakers in The Center Bandung usually use the everyday intimate language as the representative of positive politeness. The writers observe the native speakers' way is very effective to make the native speakers as the teachers close to the members as their students. It makes the students have close relationship and regard the teacher as friends. Then, it makes the students speak English courageously and actively in 
front of the teacher and friends.

The main purpose of this study is to investigate the strategies of conveying speaker and hearer as cooperators used by the speakers in conversation class and to find out the perlocutionary effects of the strategy use. The social variables is also paid attention in this conversation class. The research questions of this study, therefore, are worded as follow: (1) What the strategy used by the speakers to the Indonesians as the hearers?, (2) What speakers' intended meaning when using the strategy of the strategies of conveying speaker and hearer as cooperators?, (3) What perlocutionary effect showed by the hearers?, and (4) What social variables that constitutes a background for the speaker when using the strategy?

To find out the research questions, the writers will use some theories. The first one is Pragmatics as the study of the relationship between linguistic forms and the users of those forms. With the guidance of pragmatics, we can find out speakers' intended meaning, their assumption, their purposes or goals, and the kind of action, such as, request and statement. Those ways can be performed by the speakers when they speak. McManis et al. (1987: 197) connected speaker meaning to pragmatics: "We can see that pragmatics does more than just "fill in the details". Pragmatics concerns itself with how people use language within context and why they use language in particular ways." It can be concluded that pragmatics is the study that allows us to interpret the meaning of speech because it involves a context that helps us see the situation around and then help to understand their meaning.

In interpreting speaker's meaning, the context also has important role because the context influence utterances interpretation. The context makes the writers easier find out the surroundings and the utterance meaning because the writers not only hear the speaker utterances but also see the context that put a background of speakers when saying something. McManis et al. (1987:197) mention that the context can help determine the meaning of an utterance. They divided the context into four types: 1) Physical Context (where the conversation takes place, what objects are present, and what actions are taking place), (2) Epistemic Context (background knowledge shared by the speakers and hearers), (3) Linguistic Context (consists of utterances previous to the utterance under consideration, (4) Social Context (the social relationship and setting of the speakers and hearers). The context supports the interpretation of speaker's utterances. Without those aspects, it will be hard to understand the speaker's utterance. The context is very useful and helpful to interpret speaker's meaning.

Speech act theory will be used to interpret action in the speaker's utterances. The action performed by producing utterances has many forms so that we have to pay attention to the intended meaning of utterances in order to interpret the exact meaning or goal.

According to Yule (1996: 48), on any occasion, the action performed by producing an utterance will consist of three related acts, there are: (1) Locutionary act, which is the basic act of utterance, or producing a meaningful linguistic expression. Example: I've just made some coffee. (2) Illocutionary act, which is performed via the communication force of utterance. We might utter I've just made some coffee to make statement, an offer, an explanation, or for some other communicative purpose. (3) Perlocutionary act, which is we 
don't simply create an utterance with a function without intending it to have an effect. Depending on the circumstances, you will utter I've just made some coffee on the assumption that the hearer will recognize the effect you intended. Based on the explanations above, the writers consider that locutionary act, illocutioanary act, and perlocutionary act are the series of action performed by producing utterances. It shows that the statement is not meaningless utterances but meaningful utterances that can contain some purposes like offering, inviting, commanding, etc. In this research the perlocutionary act will be used to find out the perlocutionary effect showed by the hearers.

The writers also pay attention to social variables showed in the conversation. Social variable is the part of sociolinguistics. Stockwell (2002:1) describes sociolinguistics toolkit, those are all language event consist of a piece of language in a social context, every different social context determines that particular form of language, and the language used in particular situations determines the nature of that social event. The social variable is the factor that determines a variation in language. Possible social factors include age, geography, and so on (Stockwell, 2002:3). Brown and Levinson (1987) state that P (Power), D (Distance), R (Rank) are crucial in determining the level of politeness that will be used by the speaker. Brown and Levinson state that $\mathrm{P}, \mathrm{D}, \mathrm{R}$ are important variables that take place in utterance and they call them social variables. In addition, Brown and Levinson (1987) state that human agents use personal experience, background knowledge, and cultural norms to determine the values for these variables.

1) Social distance often depends on how well $\mathrm{S}$ (Speaker) and H (Hearer) know one another, but also on social class and status. In Brown and Levinson theory (1987) about social distance, they state that the parameter of distance is called distant if the interlocutors do not know each other (e.g. strangers), whereas the distance is close if the interlocutors know each other or perceptually 'similar' in social terms. Brown and Levinson (1987) adds the example of social distance, that is if siblings have close distance, but they do not explain in detail what kind of siblings because siblings that live separately and rarely communicate cannot be called close.

2) Power comes from many sources, but often arises from the ability of $S$ to control access to goods that $\mathrm{H}$ wants such as a money, in addition, Brown and Levinson (1987) state that power is degree to which $\mathrm{H}$ can impose own plans and it usually happens if $\mathrm{H}$ has

3) The ranking of imposition or degree of imposition, $\mathrm{Rx}$, of an act on the positive or negative face of the hearer, a culturally and situationally defined ranking of imposition by the degree to which an action is considered to interfere with an agent's wants of approval and self-determination (i.e autonomy). Autonomy is freedom of action and freedom from imposition by other-negative face or it can be stated that ranking of imposition relies on the fact that all agents' basic desires include the desire for autonomy and approval (a positive self-image that is appreciated and approved of by others-positive face). This particular speech act types can be ranked as higher impositions simply by how they relate to agents' basic desire. Ranking of imposition is also defined as Absolute Ranking of imposition in the culture in the terms of the expenditures of goods and/ or 
services by the hearer, the right speaker to perform the act, and the degree to which the hearer welcomes the imposition.

\section{The Strategies of Conveying that Speaker and Hearer are Cooperators}

One of major classes of positive politeness strategies is conveying that the speaker and the addressee are cooperatively involved in relevant activity. Because of that, in the conversation, if speaker and hearer are cooperating, they will share goals in some domain, and thus to convey that they as cooperators can serve to redress hearer's positive want. It relates to the positive consistent self-image or personality. Hearer's positive face is connected to hearer's self image to be appreciated and approved of. Yule (1996:62) states a person's positive face is the need to be accepted, even liked, by others, to be treated as a member of the same group, and to know that his or her wants are shared by others.

This cooperation is important to make the conversation work well. It is because to achieve the result that will be intended by speaker and hearer. Brown and Levinson (1987:125) note six strategies in conveying that speaker and hearer are cooperators. They also explain the cooperation between speaker and hearer may be stressed by speaker's indicating knowledge of sensitivity to hearer's wants, as in output strategy of asserting or presuppose speaker's knowledge of and concerning for hearer's want. Claiming some kind of reflexivity between speaker's and hearer's wants - either that speaker wants hearer for hearer, or (by a point-of-view flip) that hearer wants speaker wants for herself. These manipulations give output strategies like offering or promising, being optimistic, including both speaker and hearer in the activity, and giving or asking for reasons. Another case shows that speaker may convey his cooperation with hearer by indicating that he believes reciprocity to be prevailing between hearer and herself that they are somehow locked into a state of mutual helping. The strategy of assuming or asserting reciprocity is derived from this means.

\section{Research Method}

The research takes place at The Center Bandung, Indonesia. The Center Bandung is located in Bandung, Indonesia. In this institution, the native speakers mostly from America, offer the Indonesian to join. The members are mostly college students from 17 to 28 . Prior to collecting data, permission is sought from the owner of The Center Bandung.

The method used in this research is descriptive qualitative method. Nazir in Whitney (2005:54) said also that the qualitative descriptive method is the search for the proper interpretation of the facts. The goal of descriptive research method is to create a description, picture or painting in a systematic, factual and accurate statement of the facts, characteristics and relationships among phenomena investigated.

The conversation was taken on $27^{\text {th }}$ March, 2013 at 1 p.m. to 5 p.m. The Center Bandung is located in Bandung, Indonesia. The writers used recorder to record the conversation at that time. The participants are two native speakers named Mr. Ronald and Ms. Christine and 6 members/students as the hearers. The participants discussed some topics. The first topic is about solving problems. The speakers asked the members, one by one, about their problems and the solution in facing the problems. Second, the topic is spontaneously extended to 
country's problem. The participants were invited to share about the cases happened recently in their country. The last, the speakers asked the hearers about the country outside Indonesia that they had visited. The students' answers are very varied and those lead the students to share the situation around the world. It is interesting because the speakers let the topic flow in the conversation class.

The data is taken from the recorded conversation. The transcript of the data is written down by the writer to find out which the strategy used by the speaker to encourage the hearers to learn and also speak English. Afterwards, the data are analyzed to find out the strategy used by the speaker, the speakers' meaning or goal, and the perlocutionary effect of the use of the strategy.

\section{Analysis and Disscusion}

Based on the explanation above, Brown and Levinson (1987) note six strategies in conveying that speaker and hearer are cooperators, those are : 1) The strategy of asserting and presupposing speaker's knowledge of and concern for hearer's wants, 2) The strategy of offering or promising, 3) The strategy of being optimistic, 4) The strategy of including both speaker and hearer in the activity, 5) The strategy of giving or asking for reasons, and 6) The strategy of assuming and asserting reciprocity.

The writer examines conversation class in the Center Bandung and finds three strategies used by the speakers to encourage the others expresses their idea in English and to encourage the addressee to use English actively in conversation class.

\subsection{The Strategy of Asserting or Presupposing Speaker's Knowledge of and Concern for Hearer's Wants}

Awareness to hearer's wants is very important to be concerned by the speaker to encourage active and interesting conversation. Brown and Levinson (1987:125) set forward one way to indicate that speaker and hearer are cooperator, and thus potentially to put pressure on hearer to cooperate with speaker, is to assert or imply knowledge of hearer's wants and willingness to fit one's own wants in with them. The negative questions discussed above may sometimes function in this way, as may utterances like the following:

1) Look, I know you want the car by 5.0, so should(n't) I go to town now? (Request)

2) I know you can't bear parties, but this one will really be good - do come! (Request/ offer).

3) I know you love roses but the florist didn't have any more, so I brought you geraniums instead. (Offer/ apology).

Similiarly in the Indonesian language, the expressions like those above are also applied in Indonesia Language. They put pressure on hearer to cooperate with speaker in order to follow the speaker with saving hearer's face. 
4) Teman-teman ingin lancar berbahasa Inggris kan, gabung dengan kita deh di The Center Bandung.

("I know you want to speak English fluently, join us at The Center Bandung, guys.")

5) Maaf Jane, aku lupa membawa bukunya tapi saya akan membawakannya besok. Oke?

("Sorry Jane, I forget bringing the book but I will bring it to you tomorrow. Oke?")

6) Kamu kan hebat nyetirnya, boleh donk nebeng?

("I know you can drive your car fast, so should I ride on for free")

Those expressions are also used by the native speaker in The Center Bandung in the conversation class. The participants in the conversation will be labeled with $\mathrm{X}$ and $\mathrm{Y} . \mathrm{X}$ refers to the student or member and Y refers to the teacher, native speaker.

(1) The context will be provided before the conversation. Firstly, the teacher, Mr. Ronald, gathers three members and asks them two make a circle in conversation class. The members haven't known each other.

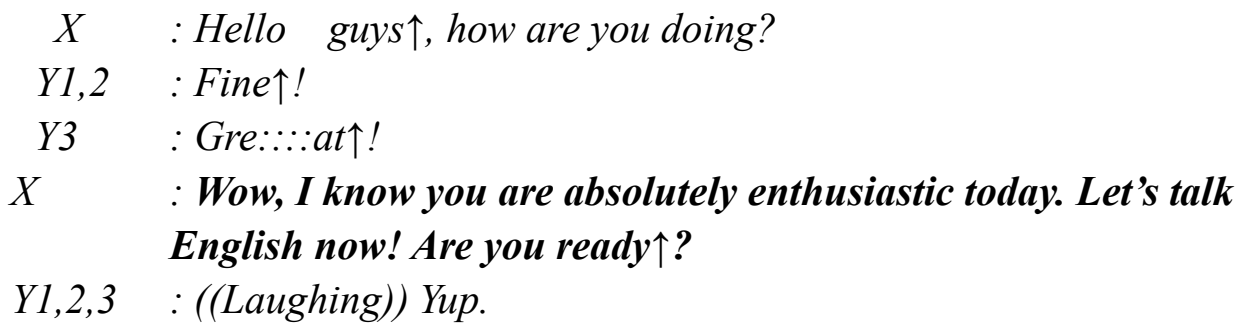

Some of them are shy to answer

$\begin{array}{lll}Y 1 & : \text { What is the topic? } \\ X & : \quad \text { //Ya } \uparrow \text { Everyone always has problems. Let's talk } \\ & \text { about the problems } \downarrow \\ Y 1 & : & / / \text { Sounds interesting. } \\ Y 2,3 & : & / / \text { Ok. }\end{array}$

In the conversation above, the speaker uses the strategy of asserting or presupposing speaker's knowledge of and concern for hearer's wants. The proof is seen in his utterances "Wow, I know you are absolutely enthusiastic today. Let's talk English now! Are you ready $\uparrow ?$ and Everyone always has a problems. Let's talk about the problems $\downarrow$ ”. Based on the teacher or the speaker's utterance, the teacher believes and then motivates his students to use English at that time. The teacher gives positive belief that the students are enthusiastic and can start to talk. In the second expression, the teacher also gives the topic of human life experience like facing problems. It invites the hearers' interest to talk about their problems which close to everyone.

The speaker concerns to the hearers' want that is to be motivated in speaking and telling the idea about their problems in English. This strategy is given by the speaker to make the 
hearers confident to speak English. The speaker understands the hearers' want with deciding the topic about life which is easily to be discussed by the hearers because it closes to person's experience. That's why the speaker chooses the topic about the problems.

When the speaker asks the hearers to start the conversation with his motivation with saying “Wow, I know you are absolutely enthusiastic today. Let's talk English now! Are you ready $\uparrow ? "$, the perlocutionary effect shown by the hearers are agreeing and trying to be ready in the conversation class. It is also seen after the speaker asks them to discuss about 'the problem', one hearer considers the topic is interesting and the others agree with that topic. The topic of life is usually easier to be talked. The writer discerns the speaker's strategy of asserting or presupposing speaker's knowledge of and concern for hearer's wants is accepted comfortably.

Relating to social variables, the social distance between the teacher and the students at the beginning are not close but the teacher tries to approach his student with asking them to start the conversation together. The teacher also uses power to encourage the students to talk English in the conversation. The ranking imposition in this conversation is high because the teacher asks or (pushes) the students to answer the question and begin the conversation. At the first time, it is hard to some students.

(1) In this session, the teacher (speaker) is Ms. Christine asks about the problems in the office. She asks the students about what problem faced by them. One student gives his experience in her office to Ms. Christine at that time.

$\mathrm{X} \quad$ : What do you do to solve the problem? What about you?

$\mathrm{Y}$ : In my work, the seniors sometimes intimidate me as the young officer $\downarrow$.

It's very common to do that here.

$\mathrm{X}$ : What do you do then?

$\mathrm{Y}:$ :Hmm (.5) I'm pretending to not see them sometimes.

$\mathrm{X} \quad$ //Ya:: you right $\uparrow$. In America,

the older sometimes intimidate the younger but mostly it is rare happened in America. It's not like here. But you are right it's much better if we ignore people like that.

The speaker uses the strategy of asserting or presupposing speaker's knowledge of and concern for hearer's wants in this session. It can be seen from these utterances: "// Ya:: you right $\uparrow$ " and "But you are right it's much better if we ignore people like that" when the student responds the speaker's question about the problems faced in her office.

Here, the teacher as speaker shows her knowledge responding the problem faced by her student as the hearer. The teacher agrees with the student's way to ignore the old worker who intimidates the young worker. The teacher concerns to student or hearer's want at that time with showing her sympathize and also agreeing the student's solution at that time. The speaker uses this way to show that she and her students as hearers are cooperators.

The perlocutionary effect showed by the student is that the student is accepted and understood by the teacher. It's seen from the teacher's respond in agreeing the student's way 
to solve her problem. This strategy is useful to revive someone's enthusiasm. It can motivate the others to do the best way in their work.

Relating to social variables, the social distance between the teacher and the students are close because in the conversation the students start sharing their opinion courageously. The teacher also gives appreciation to the student's answer with agreeing. The teacher also uses power to encourage the students to talk English in the conversation. The ranking imposition in this conversation is not high because the teacher gives opportunity to the students who want to answer the teacher's question without forcing them. The teacher also agrees with the student's opinion at that time.

\subsection{The Strategy of Including both Speaker and Hearer in the Activity}

Brown and Levinson (1987:127) considers that by using an inclusive 'we' form, when speaker really means 'you' or 'me', he can call upon the cooperative assumptions and thereby redress FTA. FTA (Face Threatening Act) is related to the utterances that represent a threat to another individual's expectation considering self-image or self-esteem.

The writer also pays attention to the use of inclusive 'we' to achieve an inclusive effect, and indeed that there may be times when using it will be counterproductive. The use of inclusive 'we' has advantages, like reducing the distances between the speaker and the hearer, helping the hearer to identify with the shared, collective effort, creating a bond or sense of connection between the speaker and the reader (between us), making an appeal to our shared human experience, emphasizing what's similar, what connects the speaker and the reader together, and placing the speaker firmly as 'one of us'.

Noting that let's in English is an inclusive 'we' form examples are :

7) Let's have a cookie, then. (i.e. me)

8) Let's get on with the dinner, eh? (i.e. you)

9) Let's stop for a bite. (i.e. I want a bite, so let's stop).

10) Give us a break (i.e. me).

The examples 4), 6) and 7) shows that the speaker wants something but he represents his wants through the use of let's that in English is an inclusive 'we' in order to involve the hearer in the activity in those cases, in 4) having a cookie and in 7) breaking. The writer also examines examples 4) and 7) as the permission to do something to hearer. It is different to example 5) because it's an offer used by the speaker to invite the hearer dinner. It means the speaker involves the hearer in the same activity that is dinner.

In Indonesian language, the inclusive 'we' form is used to soften request, pretending that speaker is as eager as hearer to have action performed:

11) Kami akan menutup pintu ini, Tuan. Acara peresmian akan segera dimulai.

("We will shut the door, Sir. The inauguration will be opened").

12) Ada yang bisa kami bantu, Bu?

("May we help you, Ma'am?") 


\section{Macrothink}

International Journal of Linguistics

ISSN 1948-5425

2013, Vol. 5, No. 3

The example 8) is often used by the Indonesian to request the guests to enter the hall room as soon as possible in order to not wait in front of the hall room. It is because sometimes they are shy to enter the hall room and choose to wait the others known. The bank officers always use the expression 9) to the customers. They use inclusive 'we' that represents that they are the bank representation. It also indicates that the officer, along with the bank, offers help or request to the customer.

The strategy of including both speaker and hearer in the activity is also used by the speaker in conversation class at The Center Bandung.

(2) At that time the, there are four members as hearers. The speaker, Mr. Ronald, hears the members' idea about the problem. The hearer asks the members about the recent news in Metro TV channel. That topic is extended to our country problem that is erritory. The speaker intends to change the topic then.

\begin{tabular}{|c|c|}
\hline $\mathrm{X}$ & $\begin{array}{l}\text { : Do you watch Metro TV recently } \downarrow \text { ? What's the hot topic in } \\
\text { Indonesia now? }\end{array}$ \\
\hline Y1 & $\begin{array}{l}\text { I think it is about the hostility in Democrat Party. The members } \\
\text { want to be the leader in that Party after the leader resigned. }\end{array}$ \\
\hline $\mathrm{X}$ & : Why? \\
\hline Y1 & : Because it is prestigious position. \\
\hline $\mathrm{X}$ & // I see. And how about you? \\
\hline Y2 & : Korupsi maybe? \\
\hline $\mathrm{X}$ & : Corruption? \\
\hline Y2 & // Ya:..:. Corruption. \\
\hline $\mathrm{X}$ & : Ya, it's also happened in America. Did they put in jail or? \\
\hline Y2 & : Yes. How about in America? \\
\hline $\mathrm{X}$ & $\begin{array}{l}\text { Ya:.:.: they got punishment in America but it depends on } \\
\text { its erritory's rule. }\end{array}$ \\
\hline Y2 & : (nodding) \\
\hline Y3 & $\begin{array}{l}\text { I think our country problem is about terrorism. People from } \\
\text { abroad regard Islam as the terrorists. }\end{array}$ \\
\hline $\mathrm{X}$ & $\begin{array}{l}\text { : (nodding) Ok, Let's change the topic. Do you ever visit the } \\
\text { country outside Indonesia? }\end{array}$ \\
\hline Y1,2 & :Ya:::::::: \\
\hline $\mathrm{Y} 2$ & : Not Yet $\downarrow$. \\
\hline
\end{tabular}

In this conversation, it can be found two expressions as the strategy of including both speaker and hearer in the activity. In the first time, the speaker invites the hearers' idea about recent news. Here, we can see the speaker uses the strategy of including both speaker and hearer in the activity. It can be known from the expressions "Do you watch Metro TV recently $\downarrow$ ? What's the hot topic in Indonesia now?" in the first question and “Ok, Let's change the topic. Do you ever visit the country outside Indonesia?" when the speaker want to change the topic. The expressions have some intensions. In the first utterance "Do you watch Metro TV recently $\downarrow$ ? What's the hot topic in Indonesia now?" indicates that the speaker includes and also invites the hearers in the speaker's activity that is talking about the news topic 
together. The speaker is not only encouraging the hearer to practice English but also involving the hearer in the activity together. The speaker's intensions influence the hearers at that time. The hearers share their knowledge about news and also give the opinion about that news. The writers observe some hearers are trying hard to express their mind even though sometimes ask their friend and the speaker (the teacher) some words in English that they haven't known, like the word in the Indonesian Language 'korupsi.' The speaker tries to give correction to the hearer as his student with saying corruption. The second utterance " $\boldsymbol{O}$, Let's change the topic. Do you ever visit the country outside Indonesia?" is used by the speaker to change the topic but keep involving the hearers to follow his topic. The speaker changes the topic about terrorism at that time because that topic is very sensitive. The writers see that the speaker avoids talking the sensitive topic that can hurt or offend the followers of Islam religion. The speaker considers that religion is the dominant religion in Indonesia. The speaker also corrects the student's word. It is because the student doesn't know the English of corruption so he mixes his talk with the Indonesian language with saying 'korupsi'.

The perlocutionary effect showed by the student is that he is motivated to tell the recent news in Metro TV. It encourages them also in practicing their English. The speaker's strategy of including both speaker and hearer in the activity makes the hearers feel that their knowledge is important to be shared because the news is connected to something new and happens recently in Indonesia. They answers the speaker's question enthusiastically. The second utterance “Ok, Let's change the topic. Do you ever visit the country outside Indonesia?" is used by the speaker to change the topic but keep involving the hearers to follow his topic. Here, the perlocutionary effect showed by the students are agreeing and accepting the teacher's request to change the topic but the student is still interested to answer new topic about visiting the country outside Indonesia. This strategy successfully invites the hearers to be involved in the topic raised by the speaker. The correction of the word 'korupsi' also is also given by the speaker instantly. It shows the speaker's knowledge even though he is an American but he knows the Indonesian Language and helps his Indonesia student. The speaker and hearers are involved in the activity together in this conversation.

In this session, the writers see the social distance between the teacher and the students are close because after talking a lot about everything. It makes the student feel comfortable to talk. But, because of the topic about terrorism is sensitive, the teacher also uses his power to change the topic at that time. The ranking imposition in this conversation is high because the teacher limits the opinion in this topic even though his purpose is good in order to respect others' feeling.

\subsection{The Strategy of Giving (or Asking) Reasons}

Involving the hearer in the conversation needs continuity talk to encourage the hearer in sharing her thoughts. It relates to hearer's wants also to share her thoughts or ideas. Brown and Levinson (1987:128) give another aspect of including hearer in the activity is for speaker to give reasons as to why he wants. By including $\mathrm{H}$ thus in his practical reasoning, and assuming reflexivity (hearer wants speaker's wants), hearer is thereby led to see the reasonableness of speaker's FTA (or so S hopes). In other words, giving reasons is a way of 
implying 'I can help you' or 'you can help me', and, assuming cooperation, a way of showing what help is needed - as example 8) above illustrates. This fact leads to pressure to go off record, to test hearer and see if he is cooperative; if he is likely to be, the context may be enough to push the off-record reason into an on-record request or offer. Thus indirect suggestions which demand rather than give reasons are a conventionalized positive-politeness form, in English:

13) Why not lend me your cottage for the weekend?

14) Why don't we go to the seashore!

15) Why don't I help you with that suitcase?

In Indonesia, the strategy of giving or asking reasons really means expecting the answer from the addressee and, sometimes, it contains demand also. The Indonesians are usually curious about others' business.

16) Kenapa anda tidak mengerjakan pekerjaan rumah?

("Why don't you finish your homework?")

17) Kenapa wanita itu tinggal sendirian di rumah sebesar itu?

("Why does the woman live alone in that big house?")

18) Bisakah anda jelaskan mengapa anda menceraikan istri anda?

(“Could you explain the reasons why do you divorce your wife?")

The teacher always asks the student "Why don't you finish your homework" because he wants to hear the explanation, at the same time, the teacher demands responsible to his student. The example 15) often used by infotainment journalist to ask the public figures involved in divorce case.

Those examples above expect reader's reply or reason as the way to extend the continuity in the conversation. It means the reader's involvement is appreciated by the speaker. The speaker also waits for the hearer reaction via his utterances when they are talking about something.

In conversation class at The Center Bandung, the writers see this way spontaneously makes the reader courageous to speak English because the addressees want to share and deliver their opinions about something.

(3) In this session, the topic is about the countries that have ever visited by the members. The teacher or the speaker, Ms. Christine, asks the students one by one to get the answer. After asking four students, another student comes and joins. The speaker asks that student who just joins at that time.

$\begin{array}{cl}\mathrm{X} & : \text { How long have you been here } \uparrow ? \\ \mathrm{Y} 1 & : \text { Emmm...... since I was child. It's about } 27 \text { years. } \\ \mathrm{X} & : \text { You know, people come around the world have the differences. } \\ & \text { Have you been anywhere, Y2? } \\ \mathrm{Y} 2 & : \text { Not yet // Hopefully } \downarrow \\ \mathrm{X} & : \quad / / \text { Yeah. }\end{array}$


$\mathrm{X} \quad$ : How about you?

Y3 : Singapore. Singapore is different from Indonesia. They always obey the rules $\uparrow$. Not like here.

$\mathrm{X} \quad$ : Ya::: here in Indonesia, when I arrived here, I'm really scared with the traffic jam and also the driver on the street. It's very crowded, right $\uparrow ?$

Y1,2,3,4: Yap $\uparrow$

Suddenly another student comes and joins.

Y5 : May, Ijoin?

$\mathrm{X} \quad$ : Sure (.2) Hey, we are talking about traveling abroad. Have you ever visited another country?

Y5 : Vietnam, Kamboja, Thailand and last month I go to Japan.

$\mathrm{X} \quad$ : What do you find there?

Y5 : In Japan, I went to International workshop. Japan is very tidy (.3) I think it's boring there.

$\mathrm{X} \quad$ : Why $\uparrow$ ?

Y5 : There is no chaos there $\uparrow$.

$\mathrm{X} \quad$ // Chaos?

Y5 : Not like in Indonesia. Everyone always does mistakes (.5) In Japan, people don't do mistake according to me.

All : (laughing)

The strategy of giving (or asking) reasons is used by the speaker to the hearers as the members in this conversation session. It can be seen in the first question "How about you?" when the speaker asks the hearer about the country that he have visited and its differences. It is also showed in speaker's utterance "Why $\uparrow$ ?" when he asks one student, Y5, the meaning of tidiness in Japan and the reasons why he is bored there.

Ms. Christine, the teacher and speaker, invites the hearers to contribute their experiences of going around the world and tells the differences among the countries through the question "How about you?" to Y3. She uses the strategy of asking hearer's experiences and reasons to make him use English and share his opinion about another country and its differences. Ms. Christine’s second request, “Why $\uparrow ?$ ?, has different intention. She not only encourages that student, Y5, to use English and share his opinion but also asks the reason why he said Japan is boring. Ms. Christine is really curious because he said that Japan is very tidy before. She would like to get her student's reasons. The speaker emphasizes that she as the speaker and the students as a hearer are cooperators.

The perlocutionary effect is clearly seen here. The teacher or speaker's question about another country that have been visited and its differences interests the members' attention. It's proved from their answer and reasons. The writers observe that the members are very enthusiastic to tell their experiences of visiting another country because it also shows their prestige and experiences to the others. They often use English even though sometimes they didn't use correct tenses in English, like saying “.... last month I go to Japan.” The point in 
this conversation is inviting the members to use English and share their opinions. It leads them to talk a lot about the experiences and the reasons of liking and disliking. In this conversation, the participants are very enthusiastic also to know the other's story. They are asking and giving the reasons each other. The speaker's intention successfully makes the members talk in this conversation session.

Relating to social variables, the social distance between the teacher and the students are very close because in the conversation the students enthusiastically share their experiences. The ranking imposition in this conversation is not high because the teacher asks the students to answer the teacher's question. Besides, the teacher asks about something that he hasn't known before to the student about Japan.

(4) The conversation continues to ask about the international workshop. The teacher, Ronald, asks Y5 about the workshop in Japan and it leads another member to find out the culture and the Japan to Y5. Another member in this conversation is curious about Japan as the country that they haven't visited.

\begin{tabular}{|c|c|}
\hline $\mathrm{X}$ & : Where do you do your International workshop? \\
\hline Y5 & : In Osaka. \\
\hline $\mathrm{X}$ & : What do you think about the event? \\
\hline Y5 & : It's very very interesting $\uparrow$. \\
\hline Y2 & : I thought there is a little who can speak English in Japan. \\
\hline Y5 & $\begin{array}{l}\text { Ya:: right but people there are very polite and kind than } \\
\text { Indonesian. }\end{array}$ \\
\hline $\mathrm{X}$ & : Why? According to me, the Indonesia are very kind. \\
\hline Y5 & than Indonesians. $\quad / / N o: \ldots$ Japanese is more kind \\
\hline $\mathrm{X}$ & : Why do say tha:::t? \\
\hline Y5 & $\begin{array}{l}\text { Ya:: People there cannot speak English. When I get lost in Japan, } \\
\text { I point the place in the map to them } \uparrow \text { and they take me to that } \\
\text { place directly even though they don't recognize me and cannot } \\
\text { speak English. They are very kind. (.5) If you ask like that in } \\
\text { Indonesia, they just say: "Ow over there" with pointing his finger } \\
\text { to somewhere. }\end{array}$ \\
\hline $\mathrm{X}$ & : $\quad$ // Yes and say \\
\hline & : (Laughing) \\
\hline
\end{tabular}

The speaker uses the strategy of giving (or asking) reasons is used by the speaker to the hearers. The utterance "Why? According to me, the Indonesia are very kind" is the first proof and the second is "Why do say tha:::t"? In the first utterance the speaker uses the strategy in giving reasons because in the first, he asks the member (hearer) and then gives the reason that as he know that the Indonesian is very kind. In the second expression, the speaker uses the strategy of asking reasons through this question "Why do say tha:::t?" to the hearer. 
In this session, the speaker intends to find out the reason why the hearer says the Japan is very kind. It's because, based on the speaker's opinion, the Indonesians are very kind. He is startled because there is another country whose citizen is more kind than the Indonesian. The speaker is curious about that so he asks to his student who has visited Japan recently. It becomes something new that has to be known by the speakers and also the others. The speaker shows that he and his students or hearers are cooperators in the conversation.

Perlocutionary effect shown after the speaker uses the strategy of giving (or asking) reasons is that the hearer is motivated pleasantly to talk a lot about his experiences facing the Japanese and their culture. He also gives new knowledge to the others about country outside Indonesia. It's clearly seen from his answers "//No:.:. Japanese is more kind than Indonesians" and "Ya:.: People there cannot speak English. When I get lost in Japan, I point the place in the map to them $\uparrow$ and they take me to that place directly even though they don't recognize me and cannot speak English. They are very kind." The student talks enthusiastically about his experiences in Japan to the teacher. Even though his grammar is not correct but the point of his grammar can be understood by the teacher.

The teacher and the students are sharing their experiences enthusiastically. The writers see the social variables at this time are different from those in the first time. The social distance between the teacher and the students are very close because in the conversation the students enthusiastically share their experiences. The ranking imposition in this conversation is not high or maybe not existed because the teacher and the student are exchanging experiences and idea. The teacher is still curious with something that he hasn't known before to the student.

\section{Conclusion}

This research is to find out the strategies used by the speakers to convey the speaker and hearer are cooperators. It is carried out within the framework of qualitative descriptive method. The data are collected from some conversations in the class at The Center Bandung.

It is crucial in showing what strategies used the speakers, in this case native speakers (the American) to encourage the Indonesian learning and speaking English courageously in conversation class. Besides, creating the students' imagination is very important in order to let their talk or story flow.

Brown and Levinson (1987) suggest six strategies to convey that the speaker and hearer are cooperators but in this research, the writers find three strategies used by the speakers in the conversation. Those are the strategy of asserting or presupposing speaker's knowledge of and concern for hearer's wants, the strategy of including both speaker and hearer in the activity, and the strategy of giving (or asking) reasons. The writers conclude that the speakers used those strategies with some intentions like motivating the students to speak English courageously, sharing the student's idea and experiences, correcting their grammar instantly, making the students confident, inviting student's imagination, and creating their curiosity. The result of these strategies can be seen from the perlocutionary effects in the research. The perlocutionary effects showed by the students as hearers are agreeing the teacher to speak 


\section{Macrothink}

International Journal of Linguistics

ISSN 1948-5425

2013, Vol. 5, No. 3

English frequently in the class, feeling accepted, being motivated to share their idea, being confident to use English, and being enthusiastic to find out new things from the others.

The social variables showed by the participants are varied. The social distance between the speaker and the hearers as the students in the first time is not close because the students are shy or afraid to talk English and share their opinion. After several minutes, they become close each other with talking a lot. The power is usually used by the speaker to ask or request the hearers (the students). The ranking of imposition in the conversation above is mostly not high because the teachers regard the students as friends. It is as the way to encourage the students to speak English and share their opinions comfortably.

\section{References}

Brown, Penelope., Levinson, C., \& Stephen. (1987). Politeness: Some Universal in language Usage. Cambridge University Press.Great Britain. pp. 72-129.

Chaer, Abdul dan Leonie Agustina. (2004). Sociolinguistics. Jakarta: Rineka Cipta.

Coulthard, Malcolm. (1977). An Introduction to Discourse Analysis. London: Longman Group.

Cummings, Louise. (2005). Pragmatics: A Multidisciplinary Perspective. Edinburg: Edinburg University Press Ltd.

Cutting, Joan. (2002). Pragmatics and Discourse. London and New York: Routledge.

Fromkin, Victoria, \& Robert Rodman. (2008). An Introduction to Language. England: Rinehart and Winston.

Grundy, Peter. (2000). Doing Pragmatics. New York: Oxford University Press Inc.Hill, et al. Leech, Geoffrey Leech. (1993). The Principles of Pragmatics. London and New York: Longman Group Limited.

Lerner, Gene H. (2004). Conversation Analysis. Amsterdam/ Philadelphia: John Benjamins Publishing Company.

Levinson, Stephen C. (1983). Pragmatics. New York: Cambridge University Press.

Lubis, A. Hamid Hasan Lubis. (1991). Analisis Wacana Pragmatik. Bandung: Penerbit Angkasa.

McManis, Carolin, Deborah Stollenwerk, \& Zhang Zheng-Sheng. (1988). Language Files. Ohio: Advocate Publishing Group.

Mey, Jacob L. (1998). Concise Encyclopedia of Pragmatics. United Kingdom: Elsevier.

Nazir, Moh. (2005). Metode Penelitian. Bogor: Dhalia Indonesia. p.54.

Richards, Jack C., \& Richard W. Schmidt. (1983). Language and Communication. London and New York: Longman. 


\section{Macrothink}

International Journal of Linguistics

ISSN 1948-5425

2013, Vol. 5, No. 3

Richards, Jack C. (1982). On Conversation. Singapore: Seameo Regional Language Centre.

Searle, John R et al. (1992). (On) Searle On Conversation. Amsterdam/ Philadelphia:John Benjamins Publishing Company.

Stockwell, Peter. (2002). Sociolinguistcs. London and New York : Routledge. pp. 3-21.

Wardhaugh, Ronald. (1986). An Introduction to Sociolinguistics. Oxford: Basil Blackwell.

Young, M., Y, C. (2006). Macao student's attitudes toward English: a post-1999 survey. World Englishes, 25(3/4), 479-490. http://onlinelibrary.wiley.com/doi/10.1111/j.1467-971X.2006.00468.x

Yule, George. (1996). Pragmatics. New York: Oxford University Press. p. 3-62.

\section{Appendix}

The Symbols used in the conversation:

// Indicates the point where talk by one speaker begins to overlap that of another.

( .) When between two words and surrounded by spaces, indicates a brief pause. (in how many second)

(( $\quad$ ) Indicates something which was not transcribed, for example, complex laughter. Indicates extra length of a sound or syllable.

$\uparrow \quad$ Indicates high intonation when speaking

$\downarrow \quad$ Indicates low intonation when pronouncing 